\title{
CD276 Gene
}

National Cancer Institute

\section{Source}

National Cancer Institute. CD276 Gene. NCI Thesaurus. Code C93063.

This gene is involved in the regulation of T cell immune responses. 